\title{
K metodě kritické teorie a jejímu rozvíjení v ,novém čtení Marxe“61
}

\section{Towards the Method of Critical Theory and its Development in „New Marx Reading"6}

\author{
Martin Nový \\ Katedra sociologie \\ Fakulta sociálních studií \\ Masarykova univerzita v Brně \\ Joštova 10, 60200 Brno \\ 216683@mail.muni.cz
}

\begin{abstract}
Abstrakt/Abstract
Tato studie se zabývá problémem metody v kritické teorii. Nejprve zkoumá ustavující texty, v nichž založili Horkheimer a Marcuse kritickou teorii jako dialektický a materialistický př́stup $\mathrm{k}$ analýze kapitalistické společnosti adekvátní její objektivněabstraktní povaze. Stat diskutuje též Hegela a Marxe, nejdůležitějš̌í předchůdce frankfurtské školy, a způsob, jímž kritická teorie čerpá z jejich děl. Dále př́spěvek obrací svou pozornost $\mathrm{k}$ Adornovým metodologickým postulátům, jež vyústily $\mathrm{v}$ analytické kategorie „reálné abstrakce“ a „objektivní konceptuality“. Reichelt a Backhaus vyšli z Adorna, jehož byli žáky, a interpretovali v tradici kritické teorie Marxovo dílo jako úsilí o zachycení určité kvality procesu inverze, v němž je práce, lidská moc ustavující společnost, nahrazena sociálním panstvím kapitalistických abstrakcí, které degradují její tvůrčí potenciál. Nové čtení Marxe dále analyzuje mizení smyslovosti v říši nadsmyslné reality kapitálu jako vůdčí hegeliánský motiv v celé Marxově práci.
\end{abstract}

The essay deals with the problem of method in Critical theory. Firstly, it explores the constituent texts in which Horkheimer and Marcuse founded Critical theory as a dialectical and materialist approach for analysing capitalist society in terms of its objectively-abstract nature. It discusses its most important predecessors - Hegel and Marx - and the way critical theory is based on their works. Secondly, the essay turns its attention to Adorno's methodological postulates that resulted into analytical categories of 'real abstraction' and 'objective conceptuality'. Building upon Adorno, their mentor, Reichelt and Backhaus interpreted, in the tradition of critical theory, Marx's oeuvre as an endeavour to catch determinate quality of the process of inversion in which labour, humanity's constituent power, is displaced and demoted by the social domination of capitalist abstractions. The neue Marx-Lektüre further analyses the disappearance of sensuousness in the realm of supersensible reality of capital as the defining Hegelian motive in Marx.

\footnotetext{
${ }^{1}$ Text stati vychází z autorovy disertační práce - viz Nový (2015).
} 


\section{Úvod}

Frankfurtská škola vešla $\mathrm{v}$ českém prostředí do širšího povědomí humanitních věd zejména svými analýzami kultury a fašismu. Práce jejích autorů se vyznačují vybroušeným stejně jako náročným stylem a množstvím neexplikovaných aluzí na filosofická a umělecká díla. To, co se méně obeznámenému čtenáři může jevit jako intelektuální nedisciplinovanost až frivolnost vzniklá v důsledku naprosté absence metody, však ve skutečnosti sytí vyhraněná noetická koncepce. V dějinách frankfurtské školy sice nikdy nedošlo k jejímu striktnímu vymezení, nicméně její základní kontury lze z textů kritických teoretiků poměrně spolehlivě rekonstruovat. Problematika kritické metodologie je i tématem této studie. Předkládaná stat' usiluje o prohloubení poznání metody kritické teorie, přičemž se zaměřuje zejména na její ,adornovskou“ linii. Ve své první části se soustředí na obecný metodologický program frankfurtské školy, který zformulovali především Horkheimer a Marcuse. V tomto oddílu se zabývá formativním vlivem, jímž působili na frankfurtskou školu její největší předchůdci Hegel a Marx. Studie se dále věnuje analýze pojmu „reálná abstrakce“, který v kontextu kritické metodologie vypracoval Sohn-Rethel, a dopadu, který měl jeho přístup na Adorna. Na Adornovy úvahy a kontemplace o metodě sociálních věd navazuje proud nového čtení Marxe (neue Marx-Lektüre), jehož východiska a hlavní objevy stat' interpretuje v prrímé návaznosti na předchozí diskusi autorů frankfurtské školy. Jednotícím tématem všech probíraných autorů je snaha o nalezení adekvátních pojmových nástrojů pro zachycení vnitřní logiky moderních kapitalistických společností. Analýza metodologických příspěvků všech studovaných autorů odhaluje výjimečný význam, který má pro kritickou metodologii konceptualizace kapitalismu, již předložil Marx v Kapitálu.

\section{Analýza kapitalistické sociální objektivity jako metodologická koncepce kritické teorie}

Jakkoli se za ustavující text, který programově vytváří metodickou distinkci mezi kritickou a tradiční teorií, obecně považuje Horkheimerův ${ }^{2}$ esej Tradiční a kritická teorie z roku 1937, lze i v ranějších dílech autorů frankfurtské školy nalézt příspěvky, jež se zabývají specifickou poznávací metodou kritické teorie. Činí tak v kontextu německého myšlení první třetiny 20. století, pročež více či méně explicitně reagují na různé varianty pozitivismu (včetně převládajícího pozitivistického - „vulgárně materialistického“ - výkladu marxismu u Druhé a Třetí internacionály), novokantovství, husserlovskou fenomenologii a rodící se existencialismus. ${ }^{3}$ Horkheimer, Marcuse a

\footnotetext{
${ }^{2}$ Horkheimer (1988).

${ }^{3}$ Zároveň však nelze říci, že by během prvního období existence Ústavu pro sociální výzkum vznikl ucelený výzkumný program - ten totiž v zásadě není vủbec možné obecně vypracovat. Sebeporozumění kritické teorie je založeno na reflexi společnosti nikoli pouze z pozice vnějšího pozorovatele, nýbrž i z vnitřku sociální reality, což ústí v celostní a dynamickou interpretaci
} 
Adorno, nejvýznamnější autoři první generace frankfurtské školy, se v oněch pionýrských dobách ustavování kritické teorie snaží o vymezení jejího metodologického statusu coby dialektické teorie kapitalistické společnosti. ${ }^{4}$ Vůdčím motivem jejich úsilí byl proto záběr na dynamickou koncepci kapitalismu, který považují za určující fenomén moderní společnosti.

Kořeny dialektického přístupu k sociální realitě v kritické teorii sahají ke klasické německé filosofii, především pak k Hegelově dialektice. Hegelův trvalý př́nos pro pochopení společenské skutečnosti spočívá $\mathrm{v}$ tom, že byl s to nahlédnout dějiny lidské civilizace jako proces, $v$ němž člověk vytváří sebe sama skrze reprodukci a přetváření duchovní reality, v níž je dějinně situován. Oproti dobovým naturalizujícím výkladům sociálních fenoménů z lidské biologie (jako byla např̀. snaha frenologie o vysvětlení jevu zločinnosti ze stavby lidské lebky) staví Hegel koncepci kvalitativních proměn lidské společnosti v dějinách, sebe-produkujícího se lidství. V biologické skutečnosti mozku a lebeční kosti ,není otisk něčeho, co by ohlašovalo svůj původ z vědomého konání“ - a „stejně“ tak „to není mozek jako animální část, co tvoří jednu stránku protikladu, nýbrž mozek jako bytí sebevědomé individuality. “5 Člověk svým jednáním sám vytváří sociální skutečnost.

„Pravým bytím člověka je ... jeho čin; v činu je činná jeho individualita, a je to čin, který překonává míněné ... čin ... není jen znak, nýbrž věc sama. “6

Lidské konání však u Hegela nevytváří společenskou realitu přímo, coby záměrná, zacílená aktivita jednotlivců. Klíčovým momentem v procesu konstituce společnosti skrze individuální jednání je jeho společenské zprostředkování rozumem, který se tak Hegelovi stává sociální substancí, tzv. věcí samou (die Sache selbst).

„,Věc sama‘ vyjadřuje struktury vzájemného zprostředkování činnosti jedinců, kteří však vědomě pracují ne pro celek, nýbrž pro dosažení svých individuálních cílů, aniž by měli celek na mysli.“7

sociální reality. Jde však o reflexi v neustále se měnících společenských podmínkách, přičemž empirický výzkum, jenž z kritické teorie metodologicky vychází, musí brát adekvátně v úvahu jak obecnou povahu naší epochy, tak její specifickou a proměnlivou sociální konfiguraci, v níž se zkoumaný jev vyskytuje. Protože kritická metodologie aspiruje na pochopení vlastní povahy zkoumaného objektu, musí se spolu se objektem pohybovat i myšlení o něm, jeho konceptualizace. Konkrétní př́stup $\mathrm{k}$ předmětu analýzy bude proto vždy ovlivněn konkrétní společenskou konstelací, jíž je zkoumaný předmět součástí. Z tohoto důvodu nemůže kritická teorie vědě o společnosti nabídnout (na rozdíl od některých proudů v pozitivismu) takřka úplné metateoretické instrukce $\mathrm{k}$ aplikaci teorií prvního řádu - pro kritickou teorii je jak (meritorní) sociální teorie, tak metateorie nerozlučitelně spojena s historicky určitou povahou objektu, který se v civilizovaných dějinách lidské společnosti vyvíjí, a tedy i kvalitativně proměňuje. Poučeně reflektuje právě naznačenou problematiku vztahu teorie prvního řádu a metateorie v kritické teorii Gunn (1992).

${ }^{4}$ Viz např. Marcuse (1936) či Adorno (1990a).

${ }^{5}$ Hegel $(1960$, s. 233, 232).

${ }^{6}$ Tamtéž, s. 227. 
Hegelovo pojetí společenské reality zdůrazňuje oproti novověkým a osvícenským teoretikům společenské smlouvy neintencionální povahu sociálního světa - jeho neredukovatelnost a principiální nepřevoditelnost na motivy, jež se nalézají ve vědomí jednotlivých sociálních aktérů. Hegelova filosofie dějin a z ní vyplývající koncepce sociální konstituce je idealistická - jde o pohyb uvnitř ideje k rozpoznání sebe sama jakožto absolutního ducha. I přesto se však pozoruhodně dotýká „,materiální reality“ práce. Ta je rovněž vyjádřením totality rozumu, což se obráží v organické skloubenosti činnosti jednotlivce a společenských potřeb. Ve Fenomenologii ducha k tomu Hegel píše:

„práce, kterou koná jednotlivec pro vlastní potřeby, je právě tak uspokojením potřeb druhých jako jeho vlastních a k uspokojení potřeb vlastních dospívá toliko prací druhých. - Jako jednotlivec ve své jednotlivé práci vykonává již nevědomky práci všeobecnou, tak vykonává také všeobecnou práci jako vlastní vědomý předmět; celek jakožto celek se stává jeho dílem, pro které se obětuje, a právě tím se od něho dostává samo zpět."

Zatímco Hegel pochopil duchovní a sociální skutečnost rodící se moderny idealisticky, jako dovršení identity dějinně se vyvíjejícího rozumu se sebou samým, kritická teorie interpretuje moderní sociální realitu v návaznosti na Marxe a jeho dialektické následovníky, myslitele jako Lukács či Korsch, coby skutečnost konstitutivně neidentickou. Rozporuplnost moderní společnosti pojímá materialisticky; odvozuje ji ze skutečnosti boje člověka s př́rodou o přežití. Kritická teorie pojednává o lidech jako o „,autorech veškerých svých životních forem“, přičemž „to, co je dáno, už nezávisí pouze na př́rodě, nýbrž také na tom, jak je člověk schopen ji ovládnout“.9 $\mathrm{Na}$ rozdíl od klasické německé filosofie neaspiruje frankfurtská škola na transcendentálně založený výklad společenské skutečnosti, ale snaží se o její imanentní vysvětlení z povahy historicky existujících sociálních vztahů, v nichž člověk produkuje sebe sama. V průběhu teoretické analýzy společenského bytí se proto kritické teorii odhaluje „nepravda, která ulpívá na každém transcendentálním probírání problému“. ${ }^{10}$

Frankfurtská škola vychází z Marxovy konceptualizace kapitalistického výrobního způsobu. Když roku 1937 Horkheimer píše, že kritická teorie na specifické vědní disciplíny ,již sedmdesát let působí osvobozujícím a podněcujícím vlivem“, odvolává se na rok 1867 , kdy poprvé vyšel první díl Kapitálu. ${ }^{11}$ Základní

\footnotetext{
${ }^{7}$ Sobotka (1981, s. 508).

${ }^{8}$ Hegel (1960, s. 244).

${ }^{9}$ Horkheimer \& Marcuse (2003, s. 617).

${ }^{10}$ Tamtéž, s. 633.

${ }^{11}$ Tamtéž, s. 618.
} 
charakteristikou kapitalismu je pro Marxe a kritickou teorii specifický charakter lidské práce v této společenské formaci. V nejjednodušším vymezení je práce u Marxe

„proces, probíhající mezi člověkem a přírodou, proces, v němž člověk svou vlastní činností zprostředkovává, reguluje a kontroluje výměnu látek mezi sebou a přírodou. (...) Aby si přivlastnil přírodní látku v určité formě vhodné pro svůj vlastní život, uvádí do pohybu přírodní síly, které patří k jeho tělu - paže i nohy, hlavu i prsty. Tím, že tímto pohybem pưsobí na vnější př́rodu a mění ji, mění zároveň svou vlastní přirozenost. “12

Tato obecná charakteristika práce, která se vztahuje k člověku jako k antropologické bytosti, je platná pro všechna historická období. Práce je tedy pro Marxe nejen základním rysem člověka, který jej odlišuje od ostatních biologických druhů, ale i nejpodstatnějším zdrojem přetváření různých civilizačních, historických forem jeho existence. Předmětem analýzy Marxova Kapitálu je zejména převládající typ společností naší éry. Abychom poznali specifický charakter moderny, je třeba obrátit pozornost ke kapitalistickým principům, jimiž se v této epoše společenské ustavování práce řídí. Základní logiku, skrze niž lidé v kapitalistických společnostech uspokojují prací své potřeby, popisuje všeobecný vzorec kapitálu $\mathrm{P}-\mathrm{Z}-\mathrm{P}^{\prime}$. Společenská výroba se v kapitalismu obecně odehrává jako produkce zboží (Z). Zboží vzniká tak, že podnikatel vloží svůj kapitál ve formě peněz $(\mathrm{P})$ do jeho produkce. Pokud se mu podaří vyrobené zboží prodat za tržní cenu, získá na konci transakce větší množství peněz $\left(\mathrm{P}^{\prime}\right)$, než jakým disponoval na začátku. Jelikož peníze v kapitalismu fungují jako všeobecná ekvivalentní forma hodnoty, dochází v procesu akumulace kapitálu k permanentnímu růstu hodnoty, který je podstatou hospodářské logiky tohoto výrobního způsobu. Kapitál, „hodnota, která se sama zhodnocuje“, je samoúčelem hospodářského života, který vůči člověku vystupuje jako autonomní mocnost a ústřední princip organizace společenského života. ${ }^{13}$ Podstata kapitalistické ekonomiky se tudíž neodvíjí od naplňování lidských potřeb. Právě naopak: lidské potřeby jsou v kapitalismu uspokojovány zbožím, a tak jsou redukovány na prostředek procesu akumulace kapitálu. Tato logika ve svém socio-historickém vývoji stále více proniká i do ostatních oblastní společenského života a kultury. Stává se v plném smyslu „všeobecným osvětlením, do něhož jsou ponořeny všechny ostatní barvy a které je modifikuje v jejich zvláštnosti““ ${ }^{14}$ Pojem kapitálu coby zhodnocující se hodnoty je předpokladem všech specifičtějších socio-ekonomických jevů, jež v moderních společnostech vyvstávají.

První generaci kritické teorie jde o takovou interpretaci sociálních fenoménů, která odhaluje jejich bezprostřední bytí jako skutečnost založenou na existenci dějinně zvláštní společenské formy. Existence kapitalismu coby historicky určité společenské

\footnotetext{
${ }^{12}$ Marx (1978, s. 184; zvýraznění MN).

${ }^{13} \operatorname{Marx}(1978$, s. 201).

${ }^{14} \operatorname{Marx}(1971$, s. 60).
} 
reality je předpokladem každého individuálního jednání, at' už je daný sociální aktér jeho věrným zastáncem, nesmiřitelným odpůrcem nebo kýmkoli jiným. Kritická teorie usiluje o takovou expozici jednajících lidí, potažmo sociálních jevů a entit, která je nestaví proti obecnému, ale předvádí jednotlivé jako zprostředkované logikou kapitalistického obecného. Namísto schematického kladení partikulárního proti univerzálnímu požaduje kritická teorie jejich metodickou totalizaci: usouvztažnění jednotlivého a obecného, jež vyústí v interpretaci partikulárního jako momentu univerzálního. Co je však onou historicky zvláštní kvalitou kapitalistické konstituce společenských jevů? Aby se tato stat' propracovala k odpovědi na tuto otázku, vyjde z Marxovy analýzy specifik kapitalistického charakteru práce.

Práce má v kapitalismu dvojakou povahu: je konkrétní a zároveň abstraktní. Pojem konkrétní práce odkazuje ke specifické lidské aktivitě, která produkuje nějak užitečné věci či služby ve formě zboží pro jiné lidi (např. stříhání vlasů u činnosti kadeřnice či stavění domu z cihel u práce zedníka). Koncept abstraktní práce odhaluje u různých druhů lidské činnosti produkující zboží jejich společnou sociální determinaci. Tou je skutečnost, že tvoří směnnou hodnotu. Abstrakce kapitalistické práce činí z užitečné činnosti zboží, které se směňuje na trhu. Zatím nechme stranou, jakým způsobem dochází $\mathrm{k}$ tomu, že se za pomoci směny ekvivalentních množství hodnoty akumuluje kapitál, tedy že prostřednictvím směny ekvivalentů dochází ke kvantitativnímu růstu hodnoty. Tento zdánlivý paradox se v textu objasní později. Prozatím se spokojme s tím, že konkrétní práce (užitečná činnost) a abstraktní práce (činnost produkující hodnotu) jsou dvě stránky jedné a té samé produkční aktivity. Jejich vztah tkví v tom, že se konkrétní práce v kapitalistickém výrobním způsobu společensky objektivizuje ve formě abstraktní práce. Konkrétní práce neexistuje mimo abstraktní práci: jakožto práce, která produkuje zboží, existuje v abstraktní práci a skrze abstraktní práci. A nejen to: konkrétní lidská činnost existuje i proti abstraktní práci.

Abstraktní práce usiluje o přivtělení konkrétní práce, čímž ji podřizuje logice produkce směnné hodnoty. Abstraktní práce si k sobě přivtěluje konkrétní činnosti, čímž ovšem reálně neguje skutečnost, že člověk svou vlastní aktivitou (prací) společensky vytváří sebe sama. „Zabstraktnění“ činnosti, která konstituuje lidskou společnost, na základě kapitalistické logiky nekonečného růstu hodnoty prakticky popírá člověka jako tvůrce sociálního života. Ustavování kapitalistické společnosti proto nutně provází rozpor, který na nejobecnější úrovni spočívá v tom, že člověk v kapitalismu je a zároveň není původcem sociálního světa. Tento rozpor v konstituci kapitalistické sociální praxe není formálně-logickým rozporem, který odhaluje chybu ve výstavbě sociální teorie, nýbrž reálným „ontologickým“ rozporem kapitalistické sociální formy. Praktickým důsledkem tohoto rozporu jsou různé způsoby rezistence lidské praxe proti jejímu abstraktnímu zpředmětňování. Člověk pocituje vưči kapitalistické objektivizaci své činnosti odpor, který se projevuje jako odmítnutí 
abstraktních imperativů společenské produkce. ${ }^{15}$ Averze vůči abstraktní práci je imanentní její existenci coby nejobecnější kvality konstituce společenské práce. Děje se tak i přesto, že si této skutečnosti jednající lidé obvykle nejsou vědomi. Vzhledem k vnitřně konfliktní povaze sociálního ustavování práce v kapitalismu neprobíhá subsumpce individuí pod celek společenských abstrakcí, během níž získávají jednotlivci abstraktní identity, hladce. Socializace člověka neústí v jeho úplné ztotožnění se s logikou existující společenské formy. Jde spíše o antagonický sociální proces, který se na úrovni partikulárního, tedy např. individuálního člověka, projevuje jako kontradikce, jako trhlina uvnitř jeho vlastního bytí. Vnitřní rozpory kapitalismu otevírají ruptury v ustavených podobách lidské subjektivity, jež $\mathrm{v}$ sociální realitě existují. Tento konstitutivní rozpor odvozuje kritická teorie od principů produkce a reprodukce kapitalistické společnosti, což z kapitalismu v kriticko-teoretickém pochopení činí jednak dynamickou sociální realitu, jednak umožňuje díky nahlédnutí vnitřní nestability kapitalismu anticipovat jeho překonání ve vyšší společenské formě.

Právě načrtnuté řešení otázky konstituce společnosti je klíčem k uchopení dialektiky v kritické teorii. Pojetí dialektiky u autorů frankfurtské školy úzce souvisí s perspektivou sociálního zprostředkování jednotlivého obecným. Na rozdíl od tradičních sociálněvědních př́stupů nejde kritické teorii primárně o odhalování bezprostředních příčin, jež ustavují výslednou empirickou podobu jednotlivého případu. Kauzální vysvětlení sociálního fenoménu pohlíží na zkoumaný předmět jako na „shrnutí mnoha určení, tedy jednotu rozmanitého“. ${ }^{16}$ Př́ičinný výklad jevu usiluje o zachycení odděleně konceptualizovaných sil, které jej s různou intenzitou ovlivňují v jistém času a prostoru. Kauzální perspektiva je však vždy omezena empirií, kterou se snaží analyzovat a popsat. Při analýze empirického materiálu, který je u společenských jevů výsledkem procesu ustavování společnosti, obvykle není s to adekvátně rozlišovat mezi tím, co v empirii vychází z podstaty společnosti, a tím, co je dočasným účinkem vzájemného propletení nejrůznějších vlivů, mezi něž mohou patřit např. generační zkušenosti, měnící se strategické zájmy jednotlivců či organizací nebo lokální kulturní zvyklosti. Tyto skutečnosti (stejně jako mnohé jiné) samozřejmě nejsou v sociální realitě nedůležité, ale vzhledem k obecné logice fungování kapitalistických společností jde o jevy odvozené, sekundární. Dialektická metoda kritické teorie usiluje oproti tomu o interpretaci jevů ve společnosti na podkladě jejich sociální podstaty, jíž jsou v moderně zákonitosti kapitalistické produkce. Tyto reálné předpoklady moderního

\footnotetext{
${ }^{15}$ Současný kritický teoretik Holloway proto nazývá momenty rebelie proti abstraktní stránce práce puklinami či prasklinami (crack): „Prasklina je negativní a nestabilní koncept. Prasklina je rupturou logiky kapitalistické koheze, přerušením struktury ovládání.“ Praskliny v procesu ustavování společnosti však mají fragmentární povahu, projevují se např. jako nechut’ $\mathrm{k}$ vykonávání zadaných pracovních úkolů a jejich sabotování či jako zesměšňování reglementovaného způsobu chování. „Revolty proti logice kapitálu existují všude“, všímá si Holloway (2010, s. 911).

${ }^{16}$ Marx (1971, s. 54).
} 
života si však naprostá většina sociálních aktérů neuvědomuje. „Konstituce světa je vykonána vždy již před veškerým faktickým jednáním individua: individuum nikdy nemůže dostat do ruky svůj nejvlastnější výkon“, píše Marcuse. ${ }^{17}$ Kritická teorie vrhá při výkladu sociálního jevu světlo na nereflektované premisy, které jsou společné nejrůznějším sférám sociálního života. Dialektická metoda proto ústí v analýzu sociálního zprostředkování: tím, že ukazuje odlišné empirické fenomény jako entity integrované totalizujícími principy akumulace kapitálu, ozřejmuje jejich vzájemné společenské propojení. Nestaví proti sobě různé oblasti sociálního života (např. politiku proti kultuře), nýbrž osvětluje jejich konstitutivní zdroj ve stejné společenské formě. ${ }^{18}$

Sociální konstituce produktivní činnosti v moderní společnosti je konfliktním procesem, jejž charakterizuje odpor proti logice abstraktní práce, která lidskou aktivitu sociálně zprostředkovává. Tato rezistence nabývá nejrůznějších podob - může jít např. o protesty, stávky a jiné mzdové boje či jen o individuální averzi vůči konkrétní dehumanizované pracovní činnosti. Z tohoto důvodu konceptualizuje kritická teorie společenské jevy a entity jako zprostředkované sociálním konfliktem, jenž je práci v kapitalistické společnosti imanentní - a to za časů Marxových a Engelsových, v polovině šedesátých let 20. století, v období keynesiánského řízení kapitalistické ekonomiky a vrcholného rozvoje sociálního státu, stejně jako dnes. Přestože došlo ve vývoji kapitalismu $\mathrm{k}$ mnoha důležitým proměnám a posunům, jeho „základní ekonomická struktura“, která je zároveň „třídním vztahem v jeho nejjednodušší podobě“, během těchto změn zůstává stabilní. ${ }^{19}$ „Společnost je stále třídní společností“, ${ }^{20}$ pročež se v rozumu, jenž ji charakterizuje, ustavuje a reprodukuje její konstitutivní antagonismus: třídní boj.

V této souvislosti je vhodné zmínit odlišnost konceptualizace „třídy“ v kritické teorii od tradičního sociologického uchopení tohoto pojmu. ${ }^{21}$ Zatímco sociologie obvykle chápe „třídu“ jako typické postavení jednotlivců v tržních interakcích, pro kritickou teorii je „třída“ předpokladem existence systému tržního hospodářství. Pro kritickou teorii je třída premisou kapitalistické ekonomiky ve dvojím smyslu. Je jí jednak na rovině logické, nebot' interakce tržních aktérů předpokládají existenci lidí, kteří získávají prostředky pro svou obživu - peníze - prodejem své schopnosti pracovat na trhu práce, a jednak na úrovni historické, jelikož existence lidí odkázaných na prodej

\footnotetext{
${ }^{17}$ Horkheimer \& Marcuse (2003, s. 626).

18 „Pokud se dá věcem, které se jeví odděleně (řekněme peníze a stát), porozumět jako různým formám jedné totality, pak to znamená, že tento proces rozumění zahrnuje kritiku jejich domnělé oddělenosti. Kritizovat $\mathrm{v}$ tomto smyslu znamená prozkoumávat vnitřní propojenost věcí“, vykládá dialektickou metodu analýzy sociálního zprostředkování v kritické teorii Holloway (1995, s. 166).

${ }^{19}$ Horkheimer (1988, s. 208).

${ }_{20}$ Adorno (1990b, s. 15).

${ }^{21}$ Ke kritickému pojmu třídy a jeho odlišnosti od tradiční sociologické konceptualizace třídy viz Nový (2014).
} 
své pracovní síly je výsledkem dějinného procesu oddělení práce od produkčních prostředků. (V předkapitalistických společnostech hrál trh při uspokojování společenských potřeb podružnou úlohu.) Kritická teorie proto nepojímá třídu jako skupinu jednotlivců definovanou jistými kritérii (at' už objektivními či subjektivními, jako jsou např̀. na jedné straně množství zdrojů, s nimiž jednotlivec do tržních interakcí vstupuje, nebo na straně druhé pojetí sociální stratifikace na základě prestiže vykonávaného povolání). Pro kritickou teorii je třídní vztah reálně existujícím společenským vztahem, jenž zachycuje přesun společensky produkovaného bohatství z jednoho pólu společnosti (práce konstituovaná jako pracovní síla neboli proletariát) $\mathrm{k}$ pólu druhému (kapitál čili buržoazie). Tř́ída proto primárně není kategorií popisující podobné situace lidí na trhu práce, ale „,sociálním vztahem, který je nezávislý na jednotlivcích, přičemž přetrvává výlučně v nich a skrze ně““.22 Třídní rozdělení společnosti na vykořist'ované činnosti a aktivity, které proces akumulace kapitálu organizují, je obecným a nutným předpokladem existence kapitalismu.

V čem spočívá dialektický materialismus kritické teorie? Jak již bylo naznačeno, jistě nejde o úsilí vykládat sociální a duchovní život primárně z jeho „hmotného“ substrátu, z biologické skutečnosti lidské tělesnosti a z fyzického světa, který člověka obklopuje - taková snaha totiž předpokládá silně ahistorickou podstatu člověka, a tudíž není s to zachytit výraznou kvalitativní proměnlivost sociálních forem v dějinách lidské civilizace. Kritická teorie oproti tomu obrací svou pozornost na reálné podmínky společenské existence člověka. Lidská podstata není nic než „,souhrn společenských vztahư", 23 a proto se

„každý pokus založit filosofii na objektivitě, ve sféře materiální reality, bez toho aby konfrontoval skutečné premisy její konceptuální povahy, tedy bez toho aby pojmul do teorie proměňující praxi ... musí vzdát svého racionálně-kritického charakteru a stát se heteronomním. Tento osud postihuje materiální nauku o esenci: vede, stejně jako v pozitivismu, k odevzdání se teorie ,daným“ silám a pořádkům.“24

V konečném důsledku tak jakýkoli ne-dialektický materialismus zůstává podobně jako idealismus uvězněn v žaláři transcendentna. Tam jej uvrhá jeho transhistorické pojímání podstaty společenského života, tedy přístup k sociálnímu světu, který považuje základní principy jeho fungování za věčné (at’ už k transcendentální perspektivě dospívá jakkoli). Každý nedialektický či vulgární materialismus se proto nevědomky zvrací v idealismus. Dialektický materialismus kritické teorie nahlíží sociální realitu v její historické kvalitativní určenosti, která prostředkuje společenské jevy a entity a má v zásadě logickou či konceptuální povahu. Projektem kritické teorie se proto stává odhalení této

\footnotetext{
${ }^{22}$ Bonefeld (2014, s. 102).

${ }^{23}$ Marx (1974, s. 7).

${ }^{24}$ Marcuse (1936, s. 17).
} 
logiky. Kritická teorie usiluje o nalezení kategorií, které reálně existují jako principy vyjadřující povahu společenské reality. Předmětem kritické teorie je proto logika či pojmy zachycující sociální produkci a reprodukci.

„Stěžejním předpokladem“, bez něhož nemůže kapitalistická společnost existovat, je „směna“. ${ }^{25}$ Je tomu tak proto, že se ve směně produkty individuálních prací reálně prokazují jako součásti společenské práce. Jinými slovy: pokud není produkt individuální činnosti na trhu směnitelný za jistou peněžní částku, nedojde k jeho společenskému potvrzení jakožto zboží s požadovanou směnnou hodnotou. Společenská abstrakce, která se vaktech směny validuje - redukce času nutného pro produkci výrobků či služeb na univerzální jednotku: na společensky průměrnou dobu, za niž se zboží daného druhu vyrobí - proto není jen pojmem, který přikládá sociální teoretik na realitu, aby se v ní byl s to zorientovat. Směnná abstrakce „leží ve společnosti samé“, a tudíž je „něco jako ,koncept“ ... implicitní ve společnosti v její objektivní formě“ ${ }^{26}$ „Prověřování“ produkční aktivity trhem je nutností, kterou musejí produkty konkrétních prací $\mathrm{v}$ kapitalistické společnosti podstupovat, aby prokázaly svou skloubenost s logikou produkce hodnoty, čili aby se prokázaly jako produkty práce abstraktní. Směnný proces je jako historicky specifický předpoklad sociální existence mimo jakoukoli společenskou diskusi - a to i přesto, že dává v procesu společenské reprodukce vzniknout rozkladným tendencím, jež vedou do „,nového barbarství“. ${ }^{27}$ Třebaže je směnná ekonomika lidským produktem, funguje její objektivita v kapitalistické epoše jako nerozpoznávaná univerzalita, která však prostředkuje všechny partikulární jevy a události. Nejrůznější kulturní praktiky se musejí realizovat v jistých hranicích; takovými způsoby a v takových podobách, v nichž jsou jejich projevy slučitelné s implicitními nároky, jež na ně kladou ekonomické imperativy. Poněvadž člověk ve společenském ustavování své práce nevědomky (a proto i nekriticky) uskutečňuje konceptuální determinaci kapitalistické ekonomiky, je abstraktní čas „,vším, člověk už není ničím; je nanejvýš vtělením času“. ${ }^{28}$ Tím, že kritická teorie analyzuje univerzalitu směnných vztahů coby skutečnost nikoli přírodní, ale jako realitu historickou, přechodnou a v zásadě změnitelnou, není pouze studiem anatomie existujících poměrů, nýbrž i „,soudem o existenci““. ${ }^{29}$ V kapitalismu se účelná lidská činnost ,podřizuje zákonům zbožního trhu, které se prosazují jako slepé ekonomické mocnosti za zády člověka““. ${ }^{30}$ Laické pochopení a orientace lidské aktivity ve společnosti vychází z bezprostřední zkušenosti, ulpívá tedy na tom, co se jeví na povrchu věci. Podobně se tomu má se všemi metodologickými př́istupy v humanitních a

\footnotetext{
${ }^{25}$ Adorno (2000, s. 31).

${ }^{26}$ Tamtéž, s. 32. Adornovo odvození směnné abstrakce coby sociální esence ze základních pojmů Marxova Kapitálu blíže analyzuji jinde - viz Nový (2016).

${ }^{27}$ Horkheimer (1988, s. 201).

${ }^{28}$ Marx (1950, s. 60).

${ }^{29}$ Horkheimer (1988, s. 201).

${ }^{30}$ Marcuse (1936, s. 6).
} 
sociálních vědách, jež se pohybují pouze na úrovni empirického uchopení studovaného fenoménu. Tradiční paradigmata nevztahují konceptualizaci studovaných jevů k esenciálním předpokladům společenské existence, které v moderně vyrůstají $\mathrm{z}$ ekonomického podloží. Kritická teorie oproti nim požaduje metodické usouvztažnění v konkrétní společenské konfiguraci vyvstalého jevu a sociální esence, jíž je v této dějinné epoše logika kapitalistické ekonomiky. Poučena Marxem, kritická teorie dobře ví, že „všechna věda by byla zbytečná, kdyby se jevová forma a podstata věci přímo kryly““ ${ }^{31}$ Pro účely vědeckého poznání sociální reality proto vyvíjí dvě sady konceptů: první z nich zachycuje skutečnost tak, jak se jeví v bezprostřednosti, coby společensky vyprodukovaný výsledek kapitalistického zvěcnění, aniž by ji nahlížela kritickým, totalizovaným prismatem (napřs. koncepty zisku a mzdy či zaměstnavatele a zaměstnance). Druhá řada konceptů pojímá sociální realitu jako vyprodukovanou na konceptuálním podloží určitých kapitalistických abstrakcí, na reálném společenském základě. Ten je však v jevových formách sociální reality důkladně zamaskován, přestože je základní premisou existence jednotlivých společenských jevů. Tato

„druhá řada konceptů odvozených z celku společenské dynamiky zachycuje podstatu a pravdivý obsah řady první, jež popisovala fenomén v jeho jevové formě“. 32

Kritická teorie odhaluje např. v pojmové konstrukci vykořist'ování produktivní práce mystiku kapitalistických sociálních forem. Falešnost moderní společnosti spočívá v tom, že se za clonou bezprostředních jevových forem skrývá ekonomická sociální podstata, která není ve společensky vyprodukovaném vědomí ulpívajícím na úrovni bezprostřednosti viditelná. Kapitalistická sociální esence moderny se nejeví jako to, čím je - jako historicky určitý společenský vztah -, ale jako něco přirozeného, a tudíž i věčného.

\section{Prohlubování metodologické kritiky: Impuls pozdního Adorna a jeho zužitkování autory neue Marx-Lektüre}

V první polovině šedesátých let se první generace frankfurtské školy nalézá v pozici, o niž po celou dobu své obtížné, politickými i akademickými problémy provázené existence usilovala: ve filosofii a humanitních oborech představuje její učení sice minoritní a opoziční, leč významný a bezpečně rozpoznávaný směr myšlení o člověku a společnosti. Přribližně touto dobou se v Německu rodí studentské protestní hnutí a na scénu takřka v téže chvíli vstupuje druhá generace kritické teorie, kterou charakterizuje „intersubjektivní obrat““ ${ }^{33}$ Ten s sebou přináší odklon od teoretického záběru na

\footnotetext{
${ }^{31}$ Marx (1980, s. 333).

${ }^{32}$ Marcuse (1936, s. 36-37).

${ }^{33}$ Hrubec (2003, s. 613).
} 
pojmové proniknutí kapitalistické sociální objektivity ve prospěch orientace na ustavené formy sociálně dosahované racionality. Za nejvýznamnějšího představitele druhé generace frankfurtské školy se obecně považuje Habermas, na jehož rozvíjení kritické teorie navazuje Honneth, jenž bývá obvykle řazen ke generaci třetí. Oba tito autoři však materialistickou dialektiku frankfurtské školy přetvářjí natolik, že se metodologicky dostávají do blízkosti teorie tradiční. ${ }^{34} \mathrm{~V}$ dalším průběhu textu se proto věnuji zejména pracím Backhause a Reichelta, tedy dílu Adornových žáků. Jejich rekonstrukce metody kritické teorie se vydává zcela opačným směrem než řešení Habermasovo či Honnethovo, aby vyústila v projekt tzv. nového čtení Marxe (neue Marx-Lektüre). ${ }^{35}$

Německé nové čtení Marxe však v 60. letech není jediným seriózním „metodologickým“ návratem k Marxovu dílu. ${ }^{36}$ Ve Francii rozvíjí Althusser přibližně ve stejné době interpretaci Marxovy metody za pomoci konceptu strukturální kauzality. ${ }^{37} \mathrm{~V}$ Itálii kladou operaističtí a autonomističtí autoři při interpretaci Kapitálu důraz na aktivitu dělnické třídy, kterou považují za hybatele vztahu práce-kapitál. ${ }^{38}$ Backhause a Reichelta ovšem podnítily k hlubšímu zájmu o Marxovo dílo zejména Adornovy přednášky. Na nich se diskutovala mj. logická či konceptuální povaha sociální reality a společná, univerzální kvalita všech partikularních věcí a činností, jež na trhu vstupují do směnných vztahů. V nejdůležitější ze svých promluv představuje Adorno interpretaci analytického jádra Marxovy Kritiky politické ekonomie. Adorno ve svém seminárním vystoupení zdůraznil, že ve směnném procesu leží „klíč ke společnosti“, přičemž koncept směny představuje „reálně společensky prováděnou

\footnotetext{
${ }^{34}$ O problémech Habermasovy a Honnethovy rekonstrukce kritické teorie jsem pojednal jinde viz Nový (2016b).

${ }^{35}$ Nové čtení Marxe není homogenním př́stupem, mezi jeho různými představiteli existují značné interpretační rozdíly. Jeho vůdčím motivem je snaha o dialektické porozumění Marxovu odvozování a rozvíjení kategorií, z čehož plyne odmítnutí různých podob ortodoxní a scientistní - at' už strukturalistické (althusserovské) či téměř nezakrytě pozitivistické (teorie racionální volby) - rekonstrukce marxismu. Někdy se mezi jeho zakladatele počítají i A. Schmidt a H.-J. Krahl, hlavní postava protestního studentského hnutí ve Frankfurtu. Krahl byl mj. Adornovým doktorandem a psal pod jeho vedením disertaci o Př́rodním zákonu (Naturgesetz) kapitalistického pohybu u Marxe. Svého učitele, s nímž se během vyvrcholení hnutí roku 1968 střetl v průběhu okupace univerzity a jehož pro odstup od protestujících, který si Adorno programově držel, ostře denuncoval, však přežil pouze o rok. Krahl zemřel v únoru 1970 při autonehodě ve věku sedmadvaceti let. Pro českého čtenáře není bez zajímavosti, že Krahl napsal a v New Left Review publikoval text Československo: dialektika ,reforem', kde analyzuje pražské jaro ve stylu Marxova Osmnáctého brumairu Ludvíka Bonaparta - viz Krahl (1969).

${ }^{36}$ Vznik neue Marx-Lektüre má rysy takřka anekdotické: datuje se rokem 1963, kdy Backhaus št’astnou náhodou objevil na studentské koleji ve Frankfurtu první německé vydání Kapitálu z roku 1867. Př̀ listování knihou si prima facie všiml významných rozdílů v podání Marxova argumentu oproti vydání druhému. Tyto odlišnosti však mohly vzbudit pozornost pouze u toho, kdo navštěvoval Adornovy semináře z letního semestru roku 1962 - viz Reichelt (2008, s. 11).

${ }^{37}$ Viz Kužel $(2013 ; 2015)$.

${ }^{38}$ Viz Wright (2002).
} 
pojmovou operaci.“39 $\mathrm{V}$ redukci nejrůznějších konkrétních podob pracovní aktivity na jistou abstraktní, „konceptuální“ kvalitu se obráží její sociální určení, jemuž právě načrtnutý proces „Zabstraktněni““ lidské práce v kapitalismu slouží. V této společenské formaci dochází k sociální mediaci konkrétní práce abstrakcí akumulace kapitálu. Přjetím principů kapitalistického zprostředkování se konkrétní práce stává prací abstraktní. Vzhledem k tomu, že všechny rozbory specifických sociálních jevů - at' už se jedná o analýzy natolik rozdílných fenoménů, jako jsou např. kulturní průmysl, geneze fašismu či proměny světa umění -, jež kritická teorie provádí, vycházejí z teze o reifikované povaze kapitalistického sociálního světa, rozpoznává Reichelt metodologickou závažnost Adornových úvah o tržní směně a trefně podotýká, že ,,celek kritické teorie závisí na přesvědčivé explikaci této ,objektivní abstrakce““. 40

Myslitelem, který podnítil Adornovo přemýšlení o primárních abstrakcích, jejichž působení na lidské jednání dává vzniknout sociální objektivitě jako historicky specifické, vůči jednotlivcům autonomní realitě, byl Sohn-Rethel. ${ }^{41}$ Jeho rekonstrukce pojmu reálné abstrakce měla značný vliv na Adornovy metodologické úvahy i na směr, jímž se později vydalo Backhausovo a Reicheltovo marxologické bádání. Ve svém nejdůležitějším díle Duševní a tělesná práce teoretizuje Sohn-Rethel, metodologický status pojmů Kritiky politické ekonomie. Dokazuje, že kategorie, jež Marx používá k odhalení kvalitativní podstaty kapitalistické ekonomiky, je nutno chápat zcela jinak než ahistorické konstrukce politické ekonomie či ideální typy. V těchto metodologických koncepcích existují teoretické pojmy pouze ve vědeckých teoriích, nikoli však v samotné sociální realitě. Tyto způsoby tvorby analytických konceptů odpovídají sociálně-nominalistickému metodologickému východisku, v němž se sociální realita chápe jako v zásadě nahodilý kontakt partikularit. Aby se byl nominalistický výzkumník schopen $\mathrm{v}$ onom fundamentálně neuspořádaném hemžení jednotlivin vyznat, vytváří teoretické koncepty, s jejichž pomocí je s to poznat alespoň některé vlastnosti jejich chaotického pohybu. Vědec zde nemá ambice pochopit společnost jako totalitu. Protože pro něj obecně nic jako sociální celek strukturovaný reálnými abstrakcemi neexistuje, je sám pojem totality, který je v metodologii kritické teorie klíčový, pro nominalistické pozitivisty prázdný.

„Neskrývá se za ním patrně nic víc než idea, že všechno nějak souvisí se vším. Jakou metodologickou výhodu může z této myšlenky vytěžit, musí ten který přístup sám dokázat. Verbální zaklínání se totalitou zde může postačit jen stěží. “42

\footnotetext{
${ }^{39}$ Adorno (2005, s. 507, 503).

${ }^{40}$ Reichelt (2007, s. 6).

${ }^{41}$ Pro hlubší pochopení způsobu, jímž Sohn-Rethel ovlivnil Adornovu metodologickou koncepci, viz Nový (2016b).

${ }^{42}$ Albert (1993, s. 207).
} 
$\mathrm{Na}$ rozdíl od ekonomického nominalismu interpretuje Sohn-Rethel Marxovu metodu analýzy zbožní formy a hodnoty coby dialektickou expozici (Darstellung) reálných abstrakcí, skrze něž se kapitalismus ve společenské skutečnosti ustavuje. ${ }^{43}$ „Původ“ sociální abstrakce, jež sídlí ve „zbožní formě“, neleží v myšlení lidí, nýbrž „, jejich činnosti““. ${ }^{44}$ Podle Sohn-Rethela vnitřně souvisí epistemologický status reálných abstrakcí s povahou teoretizovaného objektu, kterým je dějinný typ společnosti (kapitalismus), jehož základní strukturu reálné abstrakce zachycují. Předměty, jež konceptualizují přírodní vědy, tuto dimenzi bytí postrádají; jejich historicky určitá existence nemá vliv na povahu těchto objektů. Např́klad chemické vlastnosti křemíku jsou stejné dnes jako před třemi tisíci lety, zatímco podobné tvrzení v souvislosti s vlastnostmi sociální objektivity hájit nelze.

„Zatímco jsou pojmy, skrze něž poznáváme přírodu, myšlenkovými abstrakcemi, je ekonomický koncept hodnoty reálnou abstrakcí. Neexistuje sice nikde jinde než v lidském myšlení, ale v myšlení nevzniká“", 45

tvrdí Sohn-Rethel.

Abstrakce směnného procesu cejchují sociální jevy vyskytující se v kapitalistické společnosti značkou akumulace kapitálu. Zjev této historicky podmíněné skutečnosti, druhé přírody, je však v konkrétní empirické realitě k nerozeznání od toho, jak se člověku ukazuje příroda první.

„Převaha společenského je tak silná, že se společnost jeví, jako kdyby byla skutečně první př́rodou. “46

Mezi zásadně odlišným charakterem první a druhé př́rody však není společensky vyprodukované vědomí s to adekvátně diferencovat. Obě „přírody“ vystupují vůči jednotlivcům jako objektivní skutečnost, již je nutno vindividuální životní praxi respektovat a s níž je třeba uvést do souladu své jednání. Proto se individuím jeví povaha první a druhé př́rody v zásadě stejně: jako trvalá podmínka jejich životů. Specifičnost povahy reálných abstrakcí kapitalistického výrobního způsobu, které prostředkují sociální jednání jednotlivců a vyvíjejí na ně tlak, zachytil Adorno v pojmu konceptuality: „konceptualita ve směnném vztahu je sama jistým způsobem fakticity. “47 Konceptualita odkazuje kexistující, ve věcech již ustavené abstraktní podstatě společenské reality; k sociální esenci manifestující se ve světě jevů. ${ }^{48}$ Společnost

\footnotetext{
${ }^{43}$ Pojem ,reálná abstrakce‘ přebírá Sohn-Rethel od Simmela, byt’ jej naplňuje značně odlišným metodologickým obsahem; hodnotu Sohn-Rethel nechápe jako „,prafenomén“ (Simmel 2011, s. 21), ale jako historicky určitý společenský vztah - viz též Reichelt (2006, s. 16).

${ }^{44}$ Sohn-Rethel (1972, s. 41).

${ }^{45}$ Tamtéž, s. 42.

${ }^{46}$ Adorno (2005, s. 503).

${ }^{47}$ Tamtéž, s. 504.

${ }^{48}$ Srov. Bonefeld (2011, s. 382-383).
} 
„se jako reálná jednota zakládá na dynamice ,objektivní konceptuality“. Jednota společnosti má reálnou existenci ve sjednocené povaze abstraktněuniverzální práce. “49

S tímto metodologickým východiskem však stojí mezi sociálněvědními paradigmaty kritická teorie osamocena. Toho si byl ostatně dobře vědom i sám Adorno, když prohlásil, že ,v těchto otázkách se naše škola nachází v protikladu ke všem sociologickým směrům na světě“. 50

\section{Kritická teorie a historie}

Prozatím se stat' věnovala logickým a pojmovým souvislostem kritické metodologie, nyní se dotkne problému konceptualizace jejich historické geneze. Proč vzniká v lidské historii sociální panství? - Přijetím abstraktních principů panství organizuje společnost svůj zápas s př́rodou. ${ }^{51}$ Aby ovládl přírodu vnější, musí v sobě člověk do značné míry spoutat př́rodu vnitřní. Společnost se proto na úsvitu civilizovaných dějin osamostatňuje vůči jednotlivcům jako vztyčení abstraktních zákonitostí nad individuálním jednáním. Spolu se vznikem civilizace se člověk částečně vyvazuje z prrírodní souvislosti, v níž byl pevně zapuštěn. Do jisté míry osvobozuje svůj život od nahodilosti přírodních živlů a naléhavých puzení vnitřní přírody; od skutečností, které do té doby fungovaly jako nezměnitelný osud a udávaly jeho životu svůj vlastní rytmus. Společnost poskytuje člověku ochranu před nevyzpytatelností přírody a naprostou indiferencí, s níž přírodní děje vystupují vůči jednotlivému lidskému životu. Stejná společnost však lidem působí jiný druh obtíží: jak se vyrovnat s přírodou $\mathrm{v}$ nich samých; jak společensky přijatelně ovládnout démony hladu, sexu a agresivity sídlící v jejich tělech; jak se individuálně prosazovat bez toho, aby společnost a civilizace zanikly ve víru násilí hobbesovského bellum omnium contra omnes? - Daň, již za opuštění animálního modu existence člověk platí, tkví v tom, že se podrobuje zákonům panství. Jeho základní principy se opírají o více či méně systematicky reglementované usměrňování lidských pudů. S ním se pojí sociální sankcionování závazků, jež ze společenského tvarování přírodních puzení plynou. ${ }^{52} \mathrm{~K}$ sociálnímu přijetí panství se nutně váže zapomnění na jeho původ: na násilný akt, jenž založil jeho dějinně určitou, společensky platnou formu.

„Lidé museli sami na sobě provést hrozné věci, než byl vytvořen subjekt, identický, účelově zaměřený mužský charakter člověka." ${ }^{53}$

\footnotetext{
${ }^{49}$ Reichelt (2007, s. 49).

${ }^{50}$ Adorno (2005, s. 503).

51 Následující řádky se velmi letmo dotýkají problému geneze sociálního panství v kritické teorii. Komplexně toto téma uchopuje Marcuse (1956) nebo Kalivoda (1968).

${ }^{52}$ Srov. Freud (1962).

${ }^{53}$ Adorno \& Horkheimer (2009, s. 44).
} 
Třebaže se konstitutivní násilí zakrývá rouškou ctnosti a hrdinství, ze společenského života nikdy úplně nemizí: jeho podstata nadále přetrvává v přetvořené (aufgehoben) podobě v právu a sociálních normách. Násilí, které ustavilo společnost, nadále existuje jako civilizovaná normalita, aby se jakožto násilí otevřeně projevilo ve chvíli, kdy se sociální řád ocitá v ohrožení (at' už jde o hrozbu vnitřní či vnějšî). ${ }^{54}$ Koncept sociálního panství se proto nevyčerpává v nadvládě jedné skupiny lidí nad druhou; panství je stejně tak př́ítomno v samém srdci společenské reprodukce. Uznání jeho nároků je ostatně hlavní náplní procesu socializace.

Abstrakce panství, jejichž osvojení činí z člověka sociální bytost, popírají ve způsobu, kterým se ve společenské realitě jeví, svůj násilný počátek i jeho přetrvávající represivní podstatu vtělenou do společenských institucí. Dialektický materialismus kritické teorie ovšem nepojímá skutečnost panství transcendentálně, jako neměnný rys sociálního života, nýbrž v jeho kvalitativní specifičnosti, coby skutečnost historicky zvláštní. Kritická teorie tudíž $\mathrm{k}$ dějinám sociálního panství a jeho přetváření přistupuje podobně jako k analýze ekonomických abstrakcí. Již v Ekonomicko-filosofických rukopisech z roku 1844 Marx píše, že „,dějiny jsou opravdovým př́rodopisem (Naturgeschichte) člověka“. ${ }^{55}$ Kapitalistické panství se dějinně ustavilo v procesu tzv. původní akumulace kapitálu, jehož specificky násilná povaha zformovala podstatné charakteristiky konceptu kapitálu. ${ }^{56} \mathrm{~V}$ původní akumulaci kapitálu šlo o vytvoření „svobodné“ pracovní síly vyvlastněním výrobců, násilným záborem prostředků jejich existence, zejména pak půdy. Násilný původ (Ursprung) kapitalismu vyhřezá na povrch ve společenské reprodukci pouze fragmentárně, v neidentitě člověka s ustavenou podobou panství. Ta se dodnes připomíná ve skutečnosti existence sociálního vztahu třídy a odporu proti němu: v třídním boji. Jelikož ,reflexe směnné abstrakce jako filosofie ... vyžaduje odhlédnutí od (zapomnění) jejich společenské geneze, od geneze všeobecně“, leží na kritické teorii úkol, aby ve vědeckém pochopení směnného procesu skutečnost jeho krutého vzniku adekvátně zobrazila: „historický materialismus je anamnésis geneze. “57

Adornova rekonstrukce historického materialismu se však rozhodně nezakládala na encyklopedické znalosti Marxova díla. ${ }^{58}$ Podobně jako ostatní představitelé

\footnotetext{
${ }^{54}$ Srov. Benjamin (1998).

${ }_{56}^{55}$ Marx (1961, s. 143).

${ }^{56}$ Viz Marx (1978, kap. XXIV). Poučeně dialektickou interpretaci tohoto konceptu předložil Bonefeld (2011).

${ }^{57}$ Adorno (1989, s. 223).

${ }^{58}$ Např́klad všechny citace z Marxových Rukopisů ,Grundrisse‘, které se objevují na stránkách Negativní dialektiky, obstaral Adornovi Alfred Schmidt, který roku 1960 obhájil ve Frankfurtu disertační práci o Marxově pojmu přírody, viz Eldred \& Roth (1980, s. 96). Reichelt (2007, s. 4) $\mathrm{v}$ této souvislosti uvádí, že Adorno v osobních rozhovorech nijak neskrýval svou ,averzi k ekonomické problematice“ - o to překvapivější jsou jeho „brilantně intuitivní vhledy do povahy kapitalistické ekonomiky“.
} 
frankfurtské školy se i Adorno snažil zaplnit bílá místa na mapě obecné marxistické sociální teorie - at' už šlo o mezery reálně existující, či o Adornovu ne zcela zevrubnou znalost Marxovy práce - převážně za pomoci Hegelovy filosofie. ${ }^{59}$ Ačkoli šlo u Adorna do jisté míry o z nouze ctnost, ukázal se v pozdějším rozvíjení kritické teorie tento tah heuristicky mimořádně př́nosným. Úsilí autorů nového čtení Marxe o vyjasnění epistemologického statusu základních kategorií, jimiž Marx analyzoval kapitalismus, nakonec vedlo k hlubšímu pochopení pozoruhodných paralel mezi Hegelovým pojmem ducha a Marxovým konceptem kapitálu. ${ }^{60}$

\section{Dialektika v Kapitálu}

V Kapitálu začíná analýza pojmem zboží, které je „elementární formou“ kapitalistického bohatství, nebot' ,uspokojuje nějaké lidské potřeby“.61 V jeho užitečnosti leží jeho užitná hodnota. Zatímco člověk produkuje užitečné předměty a služby ve všech etapách svých civilizovaných dějin, historická výlučnost kapitalismu tkví v tom, že se dominující společenskou institucí, jež zabezpečuje naplňování lidských potřeb, stává trh. Na trhu se směňují různé druhy zboží v různých vzájemných poměrech, přičemž jejich společnou kvalitou, která stojí za (,kvantitativní“) numerikou směnných aktů, je jejich hodnota. Hodnota zboží se v tržních transakcích projevuje jako směnná hodnota. Společenská univerzalita hodnoty zboží se odhaluje tehdy, když abstrahujeme od specifických užitných hodnot. I po pomyslném „odečtení“ konkrétní užitečnosti, kterou různé druhy zboží člověku přinášejí, zbude saldo, které je určující pro pochopení zboží coby všeobecného sociálního vztahu. Jelikož je tímto společným zůstatkem hodnota zboží, stává se hodnota „společenskou substancí“, jež lidem $\mathrm{v}$ tržních interakcích zprostředkovává uspokojování jejich potřeb. ${ }^{62}$ Množství hodnoty obsažené ve zboží lze vyjádřit časem nutným pro jeho výrobu: pomocí společensky průměrné pracovní doby, během níž se zboží daného druhu vyrobí. Marx nazývá tento časový úsek ,společensky nutnou pracovní dobou“. ${ }^{63}$ Společensky nutná pracovní doba je tedy kvantitativní mírou hodnoty. Co ovšem společensky nutná pracovní doba ještě vyjadřuje? Jak již dobře víme, tak podobně jako charakterizuje zboží jednota (,smyslové“) užitné a (,pojmové“) směnné hodnoty, má i práce, která je produkuje, dvě protikladné stránky: abstraktní a konkrétní. Prací, která vytváří společensky (kapitalisticky) určitou kvalitu hodnoty, je abstraktní práce. Společensky nutná pracovní doba tedy zároveň vyjadřuje jisté kvantum abstraktní práce.

\footnotetext{
${ }^{59}$ Srov. Adorno (2005, s. 504-505).

${ }^{60}$ Reichelt (1995) ukazuje, že zásadním důvodem, proč Marx v Kapitálu záměrně skrýval svou metodu, byla snaha o popularizaci tohoto díla.

${ }^{61}$ Marx (1978, s. 51).

${ }^{62}$ Tamtéž, s. 54.

${ }^{63}$ Tamtéž, s. 55.
} 
Již u této první důležité kategoriální expozice v Kapitálu nalézají Reichelt a Backhaus hegeliánské jádro Marxovy konceptuální dialektiky. Marxovým výkladem vztahu mezi užitnou a směnnou hodnotou ve zboží stejně jako konkrétní a abstraktní práce zní echo Fenomenologie ducha. V její třetí kapitole nazvané Síla a schopnost rozvažovat: zjev a nadsmyslný svět Hegel rozpracovává vztahy mezi smyslovým světem a prvním a druhým nadsmyslným světem. První nadsmyslný svět - bezprostřední, tudíž parciální zjev smyslového světa - se v hlubší reflexi odhaluje jako prvotní, neúplný obraz, v němž se smyslový svět vyjevuje vědomí. Oproti tomu vyžaduje celostní pochopení smyslového světa metodické usouvztažnění jevové formy zkoumaného předmětu a "věci samé". V této proceduře dochází k překonání domnělých protikladů, jež existují v prvním nadsmyslném světě a jež totalizovaná perspektiva druhého nadsmyslného světa překlenuje:

„provedený rozdíl, ježto není rozdílem, je tedy zase překonán. Představuje se tím jako rozdíl věci samé či jako absolutní rozdíl, a tento rozdíl věci není tedy nic jiného než ono stejnojmenné ... a klade proto pouze protiklad, který není protikladem.“64

Druhý nadsmyslný svět v sobě obsahuje smyslový i první nadsmyslný svět, avšak ne tak, že by jednoduše shromáždil jejich prvky vedle sebe a pozitivně je v sobě sklenul. Stěžejní Hegelův objev leží v náhledu na obsahy smyslového a prvního nadsmyslného světa jako na zvrácenou, inverzní formu, v níž se Hegelovu dialektickému idealismu jeví pravá nekonečnost ducha a absolutního záporu. ${ }^{65}$

„Tak se stalo, že nadsmyslný svět, který je zvrácený svět, zároveň překryl ten druhý, a má jej v sobě samém; jest sám pro sebe světem zvráceným, tj. zvrácením sebe sama; jest sebou samým a svým protikladným světem v jediné jednotě. Jen tak jest rozdíl rozdílem vnitřním, rozdílem samým o sobě, čili jest jakožto nekonečnost. “66

Podle Reichelta dokládá zásadní vliv Hegelovy dialektiky na metodu expozice argumentu Kapitálu Marxova analýza sociální konstituce zboží. Hegelova stopa je nejprůzračněji patrná z formulace, že ,z produktů práce se stávají zboží, věci smyslově nadsmyslné čili společenské.“67 Proč tomu tak je? - Zboží pro Marxe představuje protikladnou jednotu užitné a směnné hodnoty, což znamená, že ve zboží je vždy zpředmětněna jistá konkrétní práce, která však dokládá svou sociální validitu tím, že se v aktu směny prokazuje jako výraz práce abstraktní. Nahlíženo optikou vztahu

\footnotetext{
${ }^{64}$ Hegel (1960, s. 138).

${ }^{65}$ Oproti tomu Hegelův pojem ,špatné nekonečnosti“ v zásadě odkazuje k cirkulárnímu pohybu myšlení o světě, který ulpívá na úrovni neomezených permutací jevi̊, aniž by se propracovával $\mathrm{k}$ jejich esenci.

${ }^{66}$ Tamtéž, s. 141.

${ }^{67} \operatorname{Marx}(1978$, s. 87).
} 
smyslově-konkrétního a abstraktně-univerzálního, zbožní forma užitečných věcí a činností odpovídá Hegelovu druhému nadsmyslnému světu, který v sobě zahrnuje jak smyslový svět (u Marxe pojmy konkrétní práce a její užitečnosti čili užitné hodnoty), tak první svět nadsmyslný (u Marxe kategorie abstraktní práce a hodnoty). Tím se však homologické prvky Marxovy metody konceptualizace kapitalismu a Hegelovy dialektiky zdaleka nevyčerpávají. Marx totiž začíná od čtvrté a páté kapitoly Kapitálu pojímat hodnotu, společenskou substanci zboží, nejen coby koncept tzv. jednoduchého oběhu zboží, v němž obecně platí princip quid pro quo, ale exponuje ji jako jádro zhodnocovacího procesu kapitálu. Tím dospívá ke konceptu kapitálu jako hodnoty $v$ pohybu.

Na trhu se ovšem směňuje i jedno zvláštní zboží, jehož užitná hodnota spočívá v tom, že je s to vyrobit více hodnoty, než kolik za něj zaplatí jeho kupec. Oním zbožím je pracovní síla. ${ }^{68}$ Nákupem pracovní síly, kterou dělník na trhu prodává a která se v pracovním procesu zpředmětňuje $\mathrm{v}$ produktu dělníkovy konkrétní práce, získá kapitalista posléze větší množství hodnoty, než vložil do jeho výroby. Poté, co kapitalista realizuje vyprodukovanou nadhodnotu na trhu - učiní tak prodejem zboží, jež se vyrobilo v pracovním procesu -, přivlastní si ji ve formě zisku. Se ziskem může disponovat podle své libovůle, nicméně pokud nechce dříve či později podlehnout $\mathrm{v}$ konkurenčním boji s jinými kapitalisty, bude větší část utrženého zisku znovu investovat do výrobního procesu. To může mít bud' „kvantitativní“ podobu - rožšířní produkčních kapacit - či formu „kvalitativní“, která spočívá v technologické inovaci výrobního procesu. Reálně samozřejmě dochází v závislosti na konkrétních okolnostech

${ }^{68}$ Následující pasáž se zaměřuje na jádro Marxova konceptu vykořist'ování živé práce v kapitalismu, jímž je extrakce nadhodnoty z pracovní síly angažované ve výrobním procesu. Vztahy mezi dělníkem a kapitalistou, skrze něž Marx celou problematiku vykládá, však nelze chápat jako empirický popis reálného průběhu interakce skutečných lidí. $\mathrm{V}$ předmluvě $\mathrm{k}$ prvnímu vydání Kapitálu Marx (1978, s. 19) - vědom si nebezpečí „možných nedorozumění“ pro pochopení celého argumentu Kapitálu - objasňuje, že „o osoby tu jde jen potud, pokud jsou perzonifikací ekonomických kategorií, nositeli určitých třídních vztahů a zájmů“. Ve druhé kapitole tento specifický status konceptů dělníka, kapitalisty a pozemkového vlastníka znovu připomíná, když tvrdí, že ,charakterové ekonomické masky osob jsou jen perzonifikací ekonomických vztahů, jejichž nositelé jako tyto osoby vůči sobě vystupuji““ - tamtéž, s. 98. Adorno na rozdíl od marxistické ortodoxie, která proletariát nekriticky adorovala, pochopil význam Marxovy konceptualizace kapitalisty a dělníka, která vnitřně souvisí s celkovou povahou kapitalistické sociální objektivity. Specifikoval ji při kritice pozitivistických empiriků formulací, „že samo individuum, slepě podrobené obecnému, je právě v individualistické společnosti diskvalifikováno. Vystihl to kdysi pojem ,charakterové masky'; současný empirismus na to opět zapomněl,“" viz Adorno (1967, s. 28). Reichelt (1982, s. 168) prohloubil roku 1972 ve svém vystoupení na univerzitě v Kostnici interpretaci Marxova konceptu charakterové masky vyjádřením, že jde o ,portrét abstraktní negace jednotlivců, kterou si přivozují sami lidé. ... Nakolik vstupují do svých vzájemných vztahů jako individua, nejsou objektem teorie.“ Marxův pojem charakterové masky představuje podle Reichelta jistou anticipaci sociologického konceptu role, jenž je však pevně svázán se sociální objektivitou. Tím se liší od teorie rolí, kterou rozvíjejí sociologie a sociální psychologie spíše z mikroperspektivy. 
ke kombinaci jak „kvantitativního“, tak „kvalitativního“ rozvoje výrobních prostředků a produkčního procesu. Ukazuje se, že existence hodnoty je v kapitalismu na úrovni sociální objektivity nutně spojena s jejím systematickým růstem. Kapitál je tedy hodnotou, která se snaží neustále zvětšovat, aby prorůstala do nových geografických i sociálních teritorií: kapitál se účinkem své vlastní logiky jednak globalizuje a jednak expanduje ve své evoluci do všech sfér sociálního života. Stává se tak ,automaticky působícím subjektem. “69 Samočinnost kapitálu jako univerzálního subjektu sociálního pohybu, jenž funguje jako svorník partikulárních společenských sfér a jevů, není však obecnou podmínkou života civilizovaného člověka, nýbrž je specifickým rysem historicky určité společenské formace - kapitalismu.

Posledním důležitým momentem, v němž se Marxova metoda v Kapitálu podobá Hegelově dialektice a který tato studie zmiňuje pouze letmo, je analogické pojetí „zákona“. Reichelt nalézá nejjednodušší vyjádření Hegelova pojetí zákona v chápavé Gadamerově interpretaci, konkrétně ve formuli že ,zákon je to, co přetrvává v zanikání.“70 Metodologická koncepce hodnoty coby „druhého nadsmyslného světa“a kapitálu jako hodnoty v pohybu umožňuje Marxovi opustit oblast partikulárních jevů a vstoupit do řriše obecnosti, zákonů.

„Pouze když se hodnota rozvíjí jako hodnota v pohybu, lze konceptualizovat jednotu jejích forem, jak je tomu u Hegelovy koncepce zákona. “71

Třebaže by bližší rozbor této komplikované problematiky byl s to vydat na text rozsahu knihy, spokojíme se zde s tím, že v prvním dílu Kapitálu Marx přistupuje k analýze působení „všeobecného zákona kapitalistické akumulace“ jakožto zákona v empirické sociální realitě až ve trriadvacáté kapitole (z pětadvaceti), kde poprvé systematicky usouvztažňuje kapitalistickou abstraktní objektivitu a její projevy v sociální realitě. ${ }^{72}$ Marx zde obrací svou pozornost na různé socio-historické a socio-geografické fenomény, jako jsou např. bytové poměry dělníků v různých částech Anglie, specifika Irska či dopad konkrétních ekonomických krizových období na pracující třídu, aby je interpretoval na podkladě procesu akumulace kapitálu. Jakkoli jde o rozličné jevy, Marx je předvádí jako predikované na jednotném abstraktním principu růstu hodnoty; ukazuje je coby různé momenty obecného sociálního procesu, čímž dokládá existenci univerzálního společenského principu, který v sobě antagonicky sklenuje jednotlivosti. „Materializace něčeho abstraktně-všeobecného v něčem konkrétně-zvláštním“ proto

\footnotetext{
${ }^{69} \operatorname{Marx}(1978$, s. 162).

${ }^{70}$ Gadamer (1976, s. 42).

${ }^{71}$ Reichelt (2005, s. 39).

${ }^{72}$ Pro srovnání: pojem hodnoty uvádí Marx již v první kapitole Kapitálu, koncept kapitálu coby hodnoty v pohybu tematizuje $\mathrm{v}$ kapitole čtvrté a páté.
} 
představuje „primární rozpor, který je svázán s ... dalšími rozpory.“73 V tom leží podle Adornových žáků materialistické a dialektické jádro Marxových pojmových konstrukcí.

Autoři nového čtení Marxe ve svých rozborech dokládají, že se dialektika ústředních kategorií analytického aparátu Kapitálu rozvíjí po hegelovsku. Zboží představuje smyslově nadsmyslnou bezprostřední jednotu konkrétně-smyslového a abstraktně-nadsmyslného. Ve způsobu, jímž se sociální vztah kapitálu bezprostředně jeví, je smyslová a nadsmyslná dimenze zboží nerozlišitelná.

„Výčitky z idealismu se nemusí obávat každý, kdo přičte pojmovost sociální realitě. Nemíní se tím pouze konstitutivní konceptualita poznávajícího subjektu, ale i konceptualita působící ve věci samé.“74

Protože lidské vědomí nerozpoznává zboži coby projev kapitalistické konceptuality, naturalizuje jeho reálnou abstrakci. Tento dobře kamuflovaný projev společenského vztahu kapitálu, jenž je vlastní jeho určité konceptuální povaze, vytváří podstatu zbožního fetišismu. Tou je připisování sociální moci věcem, a nikoli účelné lidské činnosti, která je produkuje. Na rozdíl od Hegela i od soudobé politické ekonomie byl Marx přesvědčen o tom, že se klíč k celé problematice kapitalistické ekonomiky ukrývá ve dvojakém charakteru práce. ${ }^{75}$ Obecně-abstraktní forma společenské práce „v historickém materialismu produkčního a reprodukčního procesu“ proto vytváří „,základnu“ vědomých vztahů, které se na rozdíl od ní vymezují jako ,nadstavba.“،76 Abstraktní práce připisuje konkrétní práci svou pozitivní identitu. Koncept společenské práce je rozpolcený v sobě samém, protože abstraktní práce „univerzalizuje“ práci konkrétní. Vztah abstraktní a konkrétní práce není sjednocený, nýbrž rozporný. „Skutečnost ..., že se“ zboží „ze sebe samo pozvedá a ... fixuje se v osamostatnělé řríši ekonomických kategorií, lze vysvětlit rovněž pouze ze sebe-rozervanosti a seberozpornosti společenské práce.“77 $\mathrm{Na}$ tomto konceptuálně-materiálním základě je pak záhodno interpretovat pojem odcizení, který se váže k Marxovu ranému dílu.

Odcizení je účinkem zapomnění na genezi sociálních forem, která vyústila ve zformování společenské objektivity. Její zákonitosti v základních konturách předurčují lidské životy se stejnou lhostejností jako zákony přírody. Mladý Marx vychází při teoretizaci totality společenských abstrakcí, jež vůči jednotlivcům vystupují jako

\footnotetext{
${ }^{73}$ Backhaus (2012, s. 14).

${ }^{74}$ Adorno (1990c, s. 209). Kvůli nedokonalosti překladu citovaných vět v českém vydání eseje Sociologie a empirický výzkum zde odkazuji k německému originálu.

${ }^{75} \mathrm{~V}$ dopise Engelsovi z 24. srpna roku 1867, tedy krátce před vydáním Kapitálu, jenž poprvé vyšel 14. záŕí 1867, Marx (1957, s. 151) píše, že „to nejlepší na mé knize je ... zdůrazněný dvojaký charakter práce podle toho, vyjadřuje-li se jako užitná nebo směnná hodnota (na tom spočívá veškeré pochopení faktů).“

${ }^{76}$ Backhaus (1980, s. 112).

${ }^{77}$ Backhaus (2011, s. 52).
} 
autonomní síly, z Feuerbachovy kritiky náboženství. Ta chápe křest’anskou víru jako odcizenou projekci rodového bytí člověka na nebesa:

„kritika náboženství je předpokladem veškeré kritiky. ... Náboženství je fantastickým uskutečněním lidské podstaty, protože pravou skutečnost tato podstata nemá. “78

Již koncem roku 1843 traktuje Marx svou filosofickou práci jako projekt kritiky všech nadsmyslných, kvazi-náboženských, vůči člověku osamostatnělých sociálních institucí: „když byla odhalena posvátná podoba sebeodcizení člověka, odhalila toto sebeodcizení i v jeho neposvátných podobách. Kritika nebe se takto mění v kritiku země, kritika náboženství v kritiku práva, kritika theologie v kritiku politiky. “79 Vůdčí ideou raného Marxova díla je kritika ve vědomí naturalizovaných sociálních forem, v nichž se objektivizují rodové síly člověka. Za kořen inverze lidských sil ve zvěcnělé sociální instituce považuje již mladý Marx, jenž má před očima raně moderní společnost, kapitalistickou ekonomiku. Byt' se její konceptualizace prozatím nalézá na zárodečné úrovni, funguje i zde kapitalistická směna, o níž Marx např. ve spisku Kžidovské otázce píše emfaticky jako o „,̌̌achru“, jako základní validizační akt odcizení lidské práce od jejího tvůrčího potenciálu. ${ }^{80}$ Backhaus provádí srovnání tematiky osamostatnění sociálních forem vůči konstitutivní lidské aktivitě např́ič Marxovým dílem a případně podotýká, že „izomorfní vztah mezi různými ,formami sebeodcizení‘ je očividný““ ${ }^{81}$ Protože je „hodnota objektivizací dělníkovy abstraktně-univerzální práce“, produkuje konkrétně-smyslová práce svět objektů, aktivit a idejí, v němž je práce coby jeho ustavující instance popřena: jako taková mizí a rozpouští se v nadsmyslnu. ${ }^{82}$

„Tím, co se takto konstituuje, je převrácený (verrückte) svět, v němž se smyslovost $\mathrm{v}$ nejširším smyslu - jako užitná hodnota, práce, výměna $\mathrm{s}$ přírodou - degraduje na prostředek sebe-zvěčňování abstraktního procesu, který vytváří základ celého objektivního světa konstantní změny. “83

Konceptuálně určená determinace společenské práce překrývá skutečnost, že jejím účelem není uspokojování lidských potřeb, nýbrž kvantitativní růst hodnoty. Ten se v procesu akumulace kapitálu realizuje skrze vykořist'ování živé práce.

\footnotetext{
${ }^{78}$ Marx (1956, s. 401).

${ }^{79}$ Tamtéž, s. 402.

${ }^{80}$ Marx (1975, passim).

${ }^{81}$ Backhaus (2005, s. 24).

${ }^{82}$ Reichelt (2007, s. 33).

${ }^{83}$ Reichelt (2005, s. 46-47). Slovo „převrácený“ však plně nevystihuje dvojí význam německého pojmu „verrückt“, který znamená jak „„šílený“, tak i „přemístěný“, „posunutý“ či „vykloubený“. Marx i autoři nového čtení Marxe používají slovo „verrückt" ve smyslu, který zahrnuje oba tyto významy: formy kapitalistické sociální reality jsou ve vztahu k jednotlivcům jak monstrózní, iracionální, „vyšinutou“ skutečností, tak i nahrazením, „vymístěním“ lidské aktivity jako constituens sociálního světa abstrakcemi akumulace kapitálu.
} 
„Hodnota se jako duch musí proměnit v kapitál jako v upíra. “84

Existenci kapitálu coby nemrtvého, jejž oživuje vysávání lidské práce, však nestvrzuje pouze laické porozumění kapitalismu, nýbrž i největší část jeho ekonomických konceptualizací. Teorie „akademických ekonomů“ znají pouze ,výsledek ... nahrazení“ (Verrücktheit) sebeurčení lidské práce jejím ustavováním ve formě hodnoty. ${ }^{85}$ Jelikož zkoumají ekonomickou realitu ne jako společenský vztah, ale jako věc, zcela jim uniká její hybný, negativní moment. Proto nejsou vůbec s to uchopit sociální dynamiku kapitálu: kontradikci mezi subjektem (práce) a objektem (akumulace kapitálu). Pojmový systém třídního panství, které se uchovává v sociálním ustavování lidské práce skrze hodnotovou formu, se v ekonomii klade jako neměnná podmínka existence člověka.

\section{Závěr}

Tato stat' zaměřila svou pozornost na metodu kritické teorie. Ve své první části nastínila noetický přístup zakládajících autorů frankfurtské školy. Analýza textů, jež vymezily kritickou teorii jako svébytný filosofický a sociálněvědní myšlenkový proud, identifikovala jako její noetický model Marxův projekt Kritiky politické ekonomie. Vůdčí princip pojímání moderní společnosti vystihuje u zakladatelů frankfurtské školy formule „historicky určité reality, která se ustavuje za zády jednotlivců jako jejich společné dílo, jehož dějinně zvláštní povahu pokládají sociální aktéři za přirozenou, a proto neměnnou“. Nereflektované principy ustavování kapitalistické společnosti se ukrývají v objektivních abstrakcích charakterizujících kapitalistický výrobní způsob. Skutečnost, že sociální realita není pro sociální aktéry průhledná, vychází z toho, že se abstraktní kapitalistická povaha práce jednotlivým subjektům jeví jako přírodní skutečnost. Tato domněle nezměnitelná podmínka jejich existence je ve skutečnosti zcela historická, a tudíž i přechodná a v principu změnitelná. Falešné vědomí, převrácený odraz existence kapitalistické logiky ve vědomí člověka, není důsledkem systematického obelhávání lidí či jejich ignorance, nýbrž je klamem neoddělitelně spjatým s logickou či konceptuální povahou reprodukce kapitalistické společnosti. Kritická teorie proto usiluje o překonání fetišových jevových forem kapitalistické reality jejich metodickou expozicí na podkladě univerzální sociální logiky, která jednotlivé společenské jevy prostředkuje.

Ve druhé části obrátila studie svou pozornost k Adornovu pojmu konceptuality, jenž zachycuje existenci a působnost kapitalistických abstrakcí v reálně existujících entitách a věcech. Adornova noetická koncepce podnítila u nejbystřejších posluchačů jeho promluv hluboký zájem o metodu Marxova vrcholného díla, jenž vyústil v „,nové“ dialektické ztvárnění expozice kategoriálního aparátu Kapitálu. Nové čtení Marxe

\footnotetext{
${ }^{84}$ Bellofiore \& Riva (2015, s. 34).

${ }^{85}$ Backhaus (1992, s. 62).
} 
dochází při zkoumání epistemologického statusu a logiky odvozování základních pojmů Kritiky politické ekonomie k poznání jejich homologie s Hegelovou dialektikou. V pozadí Marxovy základní charakteristiky zboží jako „smyslově nadsmyslné“ sociální skutečnosti stojí podle Reichelta a Backhause Hegelovo učení o subsumpci smyslového a prvního nadsmyslného světa pod druhý nadsmyslný svět. Marxův koncept zbožního fetišismu, jenž se vztahuje k reálně převrácenému pojímání skutečného vztahu lidské práce a jejích produktů, souvisí se způsobem, jímž se druhý nadsmyslný svět ve Fenomenologii ducha jeví v prvním nadsmyslném světě. Druhý nadsmyslný svět vyhlíží jako pravý opak toho, čím reálně je. Nové čtení Marxe identifikuje v zájmu o nereflektovanou inverzi lidské produktivní činnosti ve zvěcnělé sociální formy, které vůči jednotlivcům vystupují jako autonomní síly, základní jednotící téma Marxova díla. Zralá Marxova práce - sofistikovaná konceptuální stavba, jejíž zář prosvěcuje mystiku kapitalistické ekonomiky - proto drží interpretační klíč k dílu mladého Marxe, u nějž se kategorie kritické analýzy kapitalismu nalézají v zárodečné formě.

Práce Backhause a Reichelta jsou cennými příspěvky k marxologickému bádání, nabízejí hluboce reflektovaný vhled do logiky kompozice Marxových analytických kategorií a jejich vzájemných vztahů. V kontextu současné kritické teorie představuje nové čtení Marxe seriózní návrat k jejím metodologickým kořenům v materialistické dialektice. Jakkoli mají díla nového čtení Marxe exegetický charakter, lze dobře uvažovat o širším využití noetického přistupu, jejž rozvíjejí. Nabízí se možnost aplikovat dialektické postupy při interpretacích sociální reality a jejího vývoje poznatky nového čtení Marxe mohou přispět k přesnější konceptualizaci a analýze probíhajících procesů a tendencí. Metodologie nového čtení Marxe se uplatní všude tam, kde zkoumaný problém vyžaduje vyjití z partikularity dat, ze syrové empirie, kterou lze smysluplně vyložit pouze celostním nahlížením na sociální dění. Důraz na rozporuplnou, nesjednocenou povahu kapitalistické sociální reality umožňuje hlouběji promýšlet univerzální zdroj jednotlivých sociálních konfliktů, jež v průběhu společenské reprodukce vznikají, a tak teoreticky artikulovat jejich vnitřní vztah k podstatě buržoazní společnosti. Nové čtení Marxe je přístupem, který je mimořádně důležitý v současné debatě o kritické teorii a který je s to inspirovat základní i aplikovaný výzkum v sociálních a humanitních vědách.

\section{Literatura}

Adorno, Th. W. (1967): „Sociologie a empirický výzkum.“ In Dialektika a sociologie, Th. W. Adorno, J. Habermas \& L. von Friedeburg, Svoboda, Praha, 1967, s. 19 35.

Adorno, Th. W. (1989): „Notizen von einem Gespräch zwischen Th. W. Adorno und A. Sohn-Rethel am 16. 4. 1965.“ In Geistige und körperliche Arbeit: Zur Theorie der 
gesellschaftlichen Synthesis. Revidierte und ergänzte Neuauflage, A. Sohn-Rethel, VCH Verlagsgesellschaft, Weinheim, 1989, s. 221-226.

Adorno, Th. W. (1990a): „Die Aktualität der Philosophie.“ In Gesammelte Schriften, Band 1: Philosophische Frühschriften, Th. W. Adorno, Suhramp Verlag, Frankfurt am Main, 1990, s. 325-344.

Adorno, Th. W. (1990b): „Gesellschaft.“ In Gesammelte Schriften, Band 8, Th. W. Adorno, Suhrkamp Verlag, Frankfurt am Main, 1990, s. 9-19.

Adorno, Th. W. (1990c): „Soziologie und empirische Forschung.“ In Gesammelte Schriften, Band 8, Th. W. Adorno, Suhrkamp Verlag, Frankfurt am Main, 1990, s. 196-216.

Adorno, Th. W. (2000): Introduction to Sociology. Polity Press, Cambridge.

Adorno, Th. W. (2005): „Theodor W. Adorno über Marx und die Grundbegriffe der soziologischen Theorie.“ In Dialektik der Wertform: Untersuchungen zur Marxschen Ökonomiekritik, H.-G. Backhaus, Ça ira, Freiburg, 2005, s. 501-513.

Adorno, Th. W. \& Horkheimer, M. (2009): Dialektika osvícenství. Filosofické fragmenty. OIKOYMENH, Praha.

Albert, H. (1993): „Der Mythos der totalen Vernunft.“ In Der Positivismusstreit in der deutschen Soziologie, ed. Th. W. Adorno, Deutscher Taschenbuch Verlag, München, 1993, s. 193-234.

Backhaus, H.-G. (1980): „On the Dialectics of the Value-Form.“ Thesis Eleven 1 (1), s. 99-120.

Backhaus, H.-G. (1992): „Between Philosophy and Science: Marxian Social Economy as Critical Theory.“ In Open Marxism, Vol. I: Dialectics and History, eds. W. Bonefeld, R. Gunn \& K. Psychopedis, Pluto Press, London, 1992, s. 54-92.

Backhaus, H.-G. (2005): „Some Aspects of Marx's Concept of Critique in the Context of his Economic-Philosophical Theory. “In Human Dignity: Social Autonomy and the Critique of Capitalism, eds. W. Bonefeld \& K. Psychopedis, Ashgate, Aldershot - Burlington, 2005, s. 13-29.

Backhaus, H.-G. (2011): Dialektik der Wertform: Untersuchungen zur Marxschen Ökonomiekritik. Ça ira, Freiburg.

Backhaus, H.-G. (2012): „Der widersprüchliche und monströse Kern der nationalökonomischen Begriffsbildung." Initiative Sozialistisches Forum [online], s. 1-17. Dostupné z: <http://www.isffreiburg.org/verlag/leseproben/pdf/backhaus-marx.adorno_lp.pdf $>$.

Bellofiore, R. \& Riva, T. R. (2015): „The Neue Marx-Lektüre: Putting the Critique of Political Economy back into the Critique of Society." Radical Philosophy 189 (January/February): 24-36. 
Benjamin, W. (1998): „Ke kritice násilí.“ In Agesilaus Santander, W. Benjamin, Hermann \& Synové, Praha, 1998, s. 48-79.

Bonefeld, W. (2011): „Primitive Accumulation and Capitalist Acumulation: Notes on Social Constitution and Expropriation.“ Science \& Society 75 (5): 379-399.

Bonefeld, W. (2014): Critical Theory and the Critique of Political Economy: On Subversion and Negative Reason. Bloomsbury, London and New York.

Eldred, M. \& Roth, M. (1980): „Translators Introduction to ,Dialectics of the ValueForm.“" Thesis Eleven 1 (1): 94-98.

Freud, S. (1962): Abriss der Psychoanalyse. Das Unbehagen in der Kultur. Fischer Bücherei, Frankfurt am Main.

Gadamer, H.-G. (1976): Hegel's Dialectic. Five Hermeneutical Studies. Yale University Press, New Haven - London.

Gunn, R. (1992): „Against Historical Materialism: Marxism as a First-order Discourse.“ In Open Marxism, Vol. II: Theory and Practice, eds. W. Bonefeld, R. Gunn \& K. Psychopedis, Pluto Press, London, 1992, s. 1-45.

Hegel, G. W. F. (1960): Fenomenologie ducha. Nakladatelství ČSAV, Praha.

Holloway, J. (1995): „From Scream of Refusal to Scream of Power: The Centrality of Work." In Open Marxism, Vol. III: Emancipating Marx, eds. W. Bonefeld, R. Gunn, K. Psychopedis \& J. Holloway, Pluto Press, London, 1995, s. 155-181.

Holloway, J. (2010): „Cracks and the Crisis of Abstract Labour.“ Antipode 42 (4): 909923.

Horkheimer, M. (1988): „Traditionelle und kritische Theorie.“ In Gesammelte Schriften, Band 4: Schriften 1936 - 1941, M. Horkheimer, Fischer Verlag, Frankfurt am Main, 1988, s. 162-216.

Horkheimer, M. \& Marcuse, H. (2003): „Filosofie a kritická teorie.“ Filosofický časopis 51 (4): 617-638.

Hrubec, M. (2003): „Horkheimer a Marcuse: tvůrci programových tezí kritické teorie.“ Filosofický časopis 51 (4): 593-616.

Kalivoda, R. (1968): „Marx a Freud.“ In Moderní duchovní skutečnost a marxismus, R. Kalivoda, Československý spisovatel, Praha, 1968, s. 45-101.

Krahl, H.-J. (1969): „Czechoslovakia: The Dialectic of the 'Reforms' “ New Left Review I/53 (January/February): 3-12.

Kužel, P. (2013): „Althusser, Marx a neempiristická teorie dějin.“ Dějiny - teorie kritika 10 (2): 191-208.

Kužel, P. (2015): „Marx, Althusser a problém metody.“ Filosofický časopis 63

(3): 379-396. 
Marcuse, H. (1936): „Der Begriff des Wesens.“ Zeitschrift für Sozialforschung 5 (1): 139.

Marcuse, H. (1956): Eros and Civilization: A Philosophical Inquiry into Freud. Routledge, London.

Marx, K. (1950): Bída filosofie: Odpověd’ na ,Filosofii bídy “ pana Proudhona. Svoboda, Praha.

Marx, K. (1956): „Úvod ke kritice Hegelovy filosofie práva.“ In Spisy, svazek I, K. Marx \& B. Engels, SNPL, Praha, 1956, s. 401-414.

Marx, K. (1957): „Marx Engelsovi, 24. srpna 1867.“ In Dopisy o ,Kapitálu“, K. Marx, SNPL, Praha, 1957, s. 148-152.

Marx, K. (1961): Ekonomicko-filosofické rukopisy z roku 1844. SNPL, Praha.

Marx, K. (1971): Rukopisy „Grundrisse“ I. Svoboda, Praha.

Marx, K. (1974): „Teze o Feuerbachovi.“ In O historickém materialismu, K. Marx \& F. Engels, Svoboda, Praha, 1974, s. 5-8.

Marx, K. (1975): „K židovské otázce.“ In O židovské otázce, K. Marx \& F. Engels, Svoboda, Praha, 1975, s. 5-40.

Marx, K. (1978): Kapitál: Kritika politické ekonomie. Díl první. Svoboda, Praha.

Marx, K. (1980): Kapitál: Kritika politické ekonomie. Díl třetí, část druhá. Svoboda, Praha.

Nový, M. (2014): „Nástin kritického konceptu třídy.“ Sociológia 46 (5): 554-578.

Nový, M. (2015): Rozprava o Adornově sociologické metodě. Disertační práce. Fakulta sociálních studií Masarykovy univerzity, Brno.

Nový, M. (2016a): „K Adornově konceptualizaci sociální podstaty moderny.“ (Stat' vyjde v časopise Historická sociologie, č. 1/2016).

Nový, M. (2016b): „K recepci Adornovy metody v aktuálních podobách kritické teorie." (Stat' vyjde v časopise Filozofia).

Reichelt, H. (1982): „From the Frankfurt School to Value-Form Analysis.“ Thesis Eleven 4 (1): 166-169.

Reichelt, H. (1995): „Why Did Marx Conceal His Dialectical Method?“ In Open Marxism, Vol. III: Emancipating Marx, eds. W. Bonefeld, R. Gunn, K. Psychopedis \& J. Holloway, Pluto Press, London, 1995, s. 40-83.

Reichelt, H. (2005): „Social Reality as Appearance: Some Notes on Marx's Conception of Reality." In Human Dignity: Social Autonomy and the Critique of Capitalism, eds. W. Bonefeld \& K. Psychopedis, Ashgate, Aldershot - Burlington, 2005, s. $31-67$.

Reichelt, H. (2006): Zur logischen Struktur des Kapitalbegriffs bei Karl Marx. Ça ira, Freiburg. 
Reichelt, H. (2007): „Marx's Critique of Economic Categories: Reflections on the Problem of Validity in the Dialectical Method of Presentation in Capital.“ Historical Materialism 15 (4): 3-52.

Reichelt, H. (2008): Neue Marx-Lektüre: Zur Kritik der sozialwissenschaftlicher Logik. VSA-Verlag, Hamburg.

Simmel, G. (2011): Filosofie peněz. Academia, Praha.

Sobotka, M. (1981): „Hegelova koncepce společenské praxe a filozofie dějin.“ Sociologický časopis 17 (5): 503-513.

Sohn-Rethel, A. (1972): Geistige und körperliche Arbeit: Zur Theorie der gesellschaftlichen Synthesis. Suhrkamp Verlag, Frankfurt am Main.

Wright, S. (2002): Storming Heaven: Class Composition and Struggle in Italian Autonomist Marxism. Pluto Press, London. 